\title{
Combined Effects of Biological and Chemical Treatment on Rice Seed Physiological and Sanitary Quality
}

\author{
Alana Emanoele Pereira ${ }^{1}$, Weliton Lucas da Silva Benites ${ }^{1}$, Luana de Carvalho Catelan ${ }^{2}$, \\ Ana Paula Silva ${ }^{1} \&$ Nadia Graciele Krohn ${ }^{3}$ \\ ${ }^{1}$ State University of Maringá, Umuarama, PR, Brazil \\ ${ }^{2}$ State University of Londrina, Londrina, PR, Brazil \\ ${ }^{3}$ Federal University of Technology-Paraná, Santa Helena, PR, Brazil \\ Correspondence: Nadia Graciele Krohn, Federal University of Technology-Paraná, Paraná, Brazil. Tel: \\ 55-45-3628-8800. E-mail: ngkrohn@utfpr.edu.br
}

Received: June 3, 2019

Accepted: July 19, $2019 \quad$ Online Published: September 15, 2019

doi:10.5539/jas.v11n15p106

URL: https://doi.org/10.5539/jas.v11n15p106

This study was financed in part by the Coordenação de Aperfeiçoamento de Pessoal de Nivel Superior-Brasil (CAPES)-Finance Code 001.

\begin{abstract}
This study aimed to evaluate the efficiency of integrated biological and chemical control of pathogens in rice seeds and their effects on seed quality. The experiment was conducted in a $2 \times 5$ factorial completely randomized design. Fungicide-treated (carboxin/thiram) and untreated rice seeds were inoculated with distilled water (control), Azospirillum brasilense, Bacillus subtilis, Pseudomonas fluorescens, or Trichoderma harzianum. Seed vigor and viability, shoot and root length, and seedling dry weight were determined. The blotter test was carried out to assess seed health. Fungicide treatment improved seed vigor and viability and reduced the incidence of fungi. Biological treatment did not enhance the physiological quality of seeds but was able to control fungi. A. brasilense, B. subtilis, P. fluorescens, and T. harzianum controlled Phoma sorghina; B. subtilis, P. fluorescens, and T. harzianum were effective against Aspergillus flavus; P. fluorescens and T. harzianum controlled Pyricularia oryzae; and T. harzianum was effective against Gerlachia oryzae.
\end{abstract}

Keywords: bioinoculant, seed pathology, vigor

\section{Introduction}

Rice (Oryza sativa) is a staple food of great economic and social importance in Brazil and several other countries. According to data from the United States Department of Agriculture (USDA), world rice production in 2018/2019 will be of 501.57 million tonnes, an increase of approximately 6.2 million tonnes compared to the 2017/2018. The largest rice producing, importing and consuming country is China. India is already the world's largest exporter of the grain. Forecast of world supply and demand for 2018/2019, production of 501.57 million tons, export of 47.37 million tons and inventory versus consumption ratio of 35.00 million tons (Companhia Nacional de Abastecimento, 2019). In 2018/2019, the yield of rice in Brazil is estimated to reach 5,994 $\mathrm{kg} \mathrm{ha}^{-1}$ (Companhia Nacional de Abastecimento, 2018).

High rice yields depend, among other factors, on seed health. Seed treatment with chemical agents is an important strategy to control phytopathogens and prevent disease transmission to other plants and areas (Corrêa et al., 2008). An alternative to chemical control is the use of biological agents, which include non-pathogenic microorganisms capable of increasing host resistance or limiting pathogen activity (Choudhary \& Johri, 2009; Busby, Ridout, \& Newcombe, 2016). Biological agents are able to combat not only seed-borne pathogens but also those present in the soil. The main microorganisms used for biological seed treatment are bacteria (such as Agrobacterium radiobacter, Bacillus spp., and Pseudomonas spp.) and fungi (such as Aspergillus spp., Chaetomium spp., Gliocladium spp., and Trichoderma spp.) (Lucca Filho \& Farias, 2012).

Some rhizobacteria promote plant growth and control diseases. The beneficial effects of root-colonizing microorganisms decrease production costs and minimize the need for pesticides, consequently reducing the 
environmental impacts associated with their use (Harthmann, Mógor, Wordell Filho, Luz, \& Biasi, 2009). For instance, studies have shown that Bacillus spp. decreases the incidence and severity of pathogen attack by inducing resistance through cytochemical changes in plant tissues (Mertz, Henning, \& Zimmer, 2009). Seed inoculation with Bacillus subtilis enhances plant growth in common bean (Custódio, Araújo, Ribeiro, Souza Filho, \& Machado Neto, 2013). Inoculation with Azospirillum brasilense increases plant dry matter, nitrogen accumulation, and grain production (Reis Junior, C. C. T. Machado, A. T. Machado, \& Sodek, 2008). Pseudomonas fluorescens and other species of the genus promote plant growth and pathogen control by inducing hormone production in plants, producing siderophores and antibiotics, and competing for space and nutrients with pathogenic microorganisms (Corrêa, Bettiol, \& Sutton, 2010).

Trichoderma is a genus of free-living and symbiotic fungi. They can survive in the soil, rhizosphere, and within plants. Trichoderma-based products are used for seed, substrate, and foliar treatment; to prevent damping-off of seedlings; and to reduce the severity of soil-borne diseases, such as those caused by Pythium, Rhizoctonia, Sclerotium, Sclerotinia, Fusarium, and Phytophthora (Pomella \& Ribeiro, 2009).

Despite the various benefits of biological agents, there is no conclusive evidence that chemical treatment affects biological agents or that their combined use can promote beneficial effects. Therefore, we aimed to investigate the efficacy of integrated chemical and biological control of seed-borne pathogens in rice and evaluate their effects on the physiological quality of seeds.

\section{Methods}

The experiment was carried out at the Seed Technology Laboratory of the Department of Agronomy of the State University of Maringá, Umuarama, Paraná, Brazil. A $2 \times 5$ factorial completely randomized design was carried out with four repetitions. A commercial seed lot of cultivar SCS 112 was used. We evaluated the physiological quality of fungicide-treated and untreated seeds inoculated with distilled water (control), A. brasilense, $B$. subtilis, $P$. fluorescens, or Trichoderma harzianum. The fungicide combination carboxin/thiram (Vitavax-Thiram $200 \mathrm{SC}^{\circledR}$ ) was used at $300 \mathrm{~mL} 100 \mathrm{~kg}^{-1}$ seed. A. brasilense (Az Total ${ }^{\circledR}$ ), B. subtilis (Accelerate $\mathrm{BS}^{\circledR}$ ), and $P$. fluorescens $\left(\right.$ Accelerate $\mathrm{PF}^{\circledR}$ ) were used at $100 \mathrm{~mL} 100 \mathrm{~kg}^{-1}$ seed. T. harzianum (Ecotrich $\mathrm{WP}^{\circledR}$ ) was used at $3 \times 10^{12}$ colony forming units $100 \mathrm{~kg}^{-1}$ seed, diluted in $300 \mathrm{~mL}$ of distilled water. For each treatment, seeds were placed in a plastic bag and received the addition of the corresponding amount of fungicide and/or biological agent. The bag was then shaken vigorously to ensure a homogeneous distribution of the agents.

Seed health was evaluated by a standard filter paper method (blotter test) using four repetitions of 100 seeds per treatment (Brazil, 2009a). Seeds were placed, $1 \mathrm{~cm}$ apart from each other, on top of three sheets of germination paper, moistened with a volume of distilled water equal to 2.5 times the weight of a dry sheet, and placed in a germination box. Each repetition was composed of four boxes containing 25 seeds each. Boxes were kept at $20 \pm 2{ }^{\circ} \mathrm{C}$ in a BOD incubator equipped with white fluorescent lamps under a photoperiod of 12:12 $\mathrm{h}$ light/darkness for 8 days. After incubation, seeds were examined individually for any sign of fungal fruiting bodies using a stereomicroscope (4-10× magnification). Fungal species were identified by comparing fruiting bodies with reference slides of identified fungal structures. Results are expressed as percentage of incidence of fungi in seeds.

The germination test was carried out with four repetitions of 50 seeds per treatment. Seeds were placed on top of two sheets of germination paper, covered with a third sheet, moistened with a volume of distilled water equal to 2.5 times the weight of a dry sheet, rolled, and placed in a BOD incubator at $25 \pm 2{ }^{\circ} \mathrm{C}$ under a photoperiod of 12:12 h light/darkness. Seeds were examined on days 5 and 10 of incubation to determine, respectively, seed vigor and viability (Brazil, 2009b).

Shoot length was determined with four repetitions of 10 seeds sown in line on the upper third of a previously moistened paper substrate, as described for the germination test. Substrates were rolled and placed vertically in a BOD incubator at $25^{\circ} \mathrm{C}$ under a photoperiod of $12: 12 \mathrm{~h} \mathrm{light/darkness.} \mathrm{After} 14$ days, the shoot length, length of the primary root, and number of seedlings were determined. Subsequently, remaining seed reserve tissue was removed, and seedlings were packed in paper bags and dried in a forced-air oven at $65^{\circ} \mathrm{C}$ for $48 \mathrm{~h}$. Seedling dry weight was determined by dividing the weight of the sample by the number of normal seedlings (Nakagawa, 1999).

Data were tested for normality by the Shapiro-Wilk test and found to be normally distributed. Analysis of variance was performed, and means were compared by Tukey's test using Sisvar version 5.3 (Ferreira, 2011). 


\section{Results}

Seed vigor was positively influenced by fungicide treatment (Table 1). Biological treatment did not increase seed vigor in comparison with control, regardless of association with fungicide treatment. A. brasilense and $P$. fluorescens, without fungicide treatment, reduced seed vigor in relation to control, B. subtilis and T. harzianum.

Seed viability was majorly affected by fungicide treatment, increasing this parameter with the use of the chemical product.

Table 1. Vigor and viability of fungicide-treated and untreated rice seeds inoculated with biological agents

\begin{tabular}{llc}
\hline \multirow{2}{*}{ Biological agent } & \multicolumn{2}{c}{ Seed vigor (\%) } \\
\cline { 2 - 3 } & Fungicide-treated & Untreated \\
\hline Control (distilled water) & $91.5 \mathrm{Aa}$ & $74.0 \mathrm{Bab}$ \\
Azospirillum brasilense & $88.0 \mathrm{Aa}$ & $63.0 \mathrm{Bbc}$ \\
Bacillus subtilis & $84.5 \mathrm{Aa}$ & $76.0 \mathrm{Aa}$ \\
Pseudomonas fluorescens & $89.0 \mathrm{Aa}$ & $57.0 \mathrm{Bc}$ \\
Trichoderma harzianum & $81.5 \mathrm{Aa}$ & $74.5 \mathrm{Aab}$ \\
\hline & & Viability (\%) \\
\cline { 2 - 3 } & Fungicide-treated & Untreated \\
\cline { 2 - 3 } & $91.7 \mathrm{~A}$ & $82.4 \mathrm{~B}$ \\
\hline
\end{tabular}

Note. Means followed by the same lowercase letter in each column or uppercase letter in each row are not significantly different (Tukey's test, $\mathrm{p}<0.05$ ).

P. fluorescens and T. harzianum reduced shoot and root length in relation to B. subtilis treatment, but no treatment changed this parameters in relation to control (Table 2).

Table 2. Shoot and root lengths of rice seedlings treated with biological agents and fungicides

\begin{tabular}{lll}
\hline Biological agent & Shoot length $(\mathrm{cm})$ & Root length $(\mathrm{cm})$ \\
\hline Control (distilled water) & $9.28 \mathrm{ab}$ & $15.11 \mathrm{ab}$ \\
Azospirillum brasilense & $9.40 \mathrm{ab}$ & $15.63 \mathrm{ab}$ \\
Bacillus subtilis & $10.26 \mathrm{a}$ & $17.90 \mathrm{a}$ \\
Pseudomonas fluorescens & $8.44 \mathrm{~b}$ & $14.31 \mathrm{~b}$ \\
Trichoderma harzianum & $8.43 \mathrm{~b}$ & $13.86 \mathrm{~b}$ \\
\hline
\end{tabular}

Note. Means followed by the same letter are not significantly different (Tukey's test, $\mathrm{p}<0.05$ ).

Seedling dry mass was determined; however, no significant differences were observed between treatments (data not shown).

For the analysis of fungi incidence on seeds (Table 3) note that a single seed can be infected by more than one species of fungus. Application of fungicide was efficient in controlling Aspergillus flavus, Pyricularia oryzae, Gerlachia oryzae and Phoma sorghina. Moreover, fungicide-treated seeds had the highest percentage of seeds without signs of fungal infection. There was no additional effect in fungi control when fungicide and biological treatment were associated.

B. subitilis, P. flourescens and T. harzianum, without application of fungicide, were able to control A. flavus and P. oryzae (Table 3). Additionally, G. oryzae was best controlled by T. harzianum, followed by A. brasilense, than by $P$. fluorescens and $B$. subitilis afterall. All inoculants were equally effective against $P$. sorghina.

Biological agents, without application of fungicide, showed different performances in combating fungi in rice seeds (Table 3). B. subtilis, P. fluorescens, and T. harzianum were more effective against A. flavus than A. brasilense. T. harzianum was the most effective in reducing the incidence of G. oryzae. Inoculation with $T$. harzianum resulted in the highest percentage of seeds without signs of fungal infection, being the only biological treatment with similar results as fungicide treatment for this evaluation. 
Table 3. Incidence (\%) of fungi in fungicide-treated and untreated rice seeds inoculated with biological agents

\begin{tabular}{|c|c|c|c|c|}
\hline \multirow{2}{*}{ Biological agent } & \multicolumn{2}{|c|}{ Aspergillus flavus } & \multicolumn{2}{|c|}{ Pyricularia oryzae } \\
\hline & Fungicide-treated seeds & Untreated seeds & Fungicide-treated seeds & Untreated seeds \\
\hline Control (distilled water) & $5.5 \mathrm{Ba}$ & $16.5 \mathrm{Aa}$ & $0.0 \mathrm{Ba}$ & $13.0 \mathrm{Aa}$ \\
\hline Azospirillum brasilense & $1.5 \mathrm{Ba}$ & $14.5 \mathrm{Aa}$ & $0.0 \mathrm{Ba}$ & $12.0 \mathrm{Aa}$ \\
\hline Bacillus subtilis & $1.0 \mathrm{Aa}$ & $3.5 \mathrm{Ab}$ & $0.0 \mathrm{Ba}$ & 6.0 Aab \\
\hline Pseudomonas fluorescens & $0.0 \mathrm{Aa}$ & $2.0 \mathrm{Ab}$ & $0.0 \mathrm{Aa}$ & $2.0 \mathrm{Ab}$ \\
\hline Trichoderma harzianum & $0.0 \mathrm{Aa}$ & $2.0 \mathrm{Ab}$ & $0.0 \mathrm{Aa}$ & $1.0 \mathrm{Ab}$ \\
\hline \multirow{2}{*}{ Biological agent } & \multicolumn{2}{|c|}{ Gerlachia oryzae } & \multicolumn{2}{|c|}{ Phoma sorghina } \\
\hline & Fungicide-treated seeds & Untreated seeds & Fungicide-treated seeds & Untreated seeds \\
\hline Control (distilled water) & $5.0 \mathrm{Ba}$ & $66.0 \mathrm{Aa}$ & $1.0 \mathrm{Ba}$ & $45.5 \mathrm{Aa}$ \\
\hline Azospirillum brasilense & 7.0 Ba & $25.0 \mathrm{Ac}$ & $12.0 \mathrm{Aa}$ & $13.5 \mathrm{Ab}$ \\
\hline Bacillus subtilis & $2.0 \mathrm{Ba}$ & $42.5 \mathrm{Ab}$ & $1.0 \mathrm{Aa}$ & $6.0 \mathrm{Ab}$ \\
\hline Pseudomonas fluorescens & $6.0 \mathrm{Ba}$ & $33.0 \mathrm{Abc}$ & $0.0 \mathrm{Aa}$ & $8.5 \mathrm{Ab}$ \\
\hline Trichoderma harzianum & $0.0 \mathrm{Aa}$ & $2.0 \mathrm{Ad}$ & $0.5 \mathrm{Aa}$ & $6.5 \mathrm{Ab}$ \\
\hline \multirow{2}{*}{ Biological agent } & \multicolumn{4}{|c|}{ Seeds without visual signs of fungal infection } \\
\hline & Fungicide-treated seeds & & Untreated seeds & \\
\hline Control (distilled water) & $90.0 \mathrm{Aa}$ & & $17.0 \mathrm{Bc}$ & \\
\hline Azospirillum brasilense & 87.0 Aa & & $35.0 \mathrm{Bbc}$ & \\
\hline Bacillus subtilis & $99.5 \mathrm{Aa}$ & & $42.0 \mathrm{Bb}$ & \\
\hline Pseudomonas fluorescens & $89.0 \mathrm{Aa}$ & & $54.5 \mathrm{Bb}$ & \\
\hline Trichoderma harzianum & $85.0 \mathrm{Aa}$ & & $88.5 \mathrm{Aa}$ & \\
\hline
\end{tabular}

Note. Means followed by the same lowercase letter in each column or uppercase letter in each row are not significantly different (Tukey's test, $\mathrm{p}<0.05$ ).

\section{Discussion}

Several studies reported the beneficial effect of fungicide treatment on seed quality (Pereira, Oliveira, Rosa, Oliveira, \& Costa Neto, 2009; Pereira et al., 2011; Silva, Lucca Filho, Zimmer, \& Bonini Filho, 2011; Hossen, Corrêa Junior, Guimarães, Nunes, \& Galon, 2014). Ramos, Marcos Filho, and Galli (2008) working with supersweet corn, observed that fungicide treatment improved seed vigor under accelerated aging conditions. Pereira et al. (2011) found that treatment of soybean seeds with fungicide increased seedling emergence by $44.3 \%$, confirming the importance of controlling naturally occurring pathogens in seeds even under optimal germination conditions. Similar beneficial effects of chemical treatment were observed on rice seed vigor and viability (Table 1$)$.

Initial seed quality determines the response of seeds to biological and chemical treatment; that is, seeds with high physiological quality do not benefit as much from treatments as do medium-quality seeds (Carvalho \& Nakagawa, 2012). This fact probably explains the little effect of biological inoculation on rice seeds viability and seedling growth in the current study.

Another observation of the present study was the reduction of seed vigor after the use of some biological treatments. These results differ from those found in literature. There are evidences showing that seeds biological treatment improves (Brotman et al., 2013) and accelerates seed germination, increases seedling vigor and ameliorates water, osmotic, salinity, chilling and heat stresses (Mastouri, Björkman, \& Harman, 2010). The interaction of the biological control agent with seeds/seedlings is complex and depends on factors such as the gene constitution of the plant (Simon et al., 2001; Smith, Tola, de Boer, \& O'Gara, 1999), the production of organic acids by it is essential for establishing plant/bacterial interaction (as reviewed by Bloemberg \& Lugtenberg, 2001), for example, and the presence of other microorganisms in the environment (Bloemberg \& Lugtenberg, 2001). The germination test is carried out on paper substrate, changing the interaction conditions that the seed and the biological treatment would find in the soil. Therefore, in the mentioned test the absence of several factors which interfere in establishing the interaction, could contribute to alter the energy balance and consequently could contribute to reduce seed vigor.

However, biological treatment on seeds can be responsible for several other advantageous effects as it will be discussed further. Some characteristics of B. subtilis make it a particularly effective seed inoculant, such as its 
sporulation ability, tolerance to desiccation, and improved survival in polymer formulations (Choudhary \& Johri, 2009). These properties probably explain the high shoot and root lengths observed in rice plants inoculated with B. subtilis (Table 2). Bacteria of the genus Bacillus are known for their versatile defense mechanisms and antagonistic activities against plant pathogens, which are required for their survival and maintenance in specific ecological niches (Lanna Filho, Ferro, \& Pinho, 2010). A study showed that inoculation of rice, common bean, chickpea, soybean, and cotton seeds with $B$. subtilis improves seed vigor, seedling emergence, and seedling dry weight (Custódio et al., 2013). In the same study, corn and cotton plants inoculated with the bacterium were found to have higher phosphorus concentrations in leaves than control plants, and inoculated corn plants were shown to absorb significantly higher amounts of phosphorus even in phosphorus-deficient soil (Araujo, 2008). $B$. subtilis is also beneficial to peanut seeds, improving plant vigor and harvest yield (Abd-Allah \& Didamony, 2007).

Additionally, other microorganisms were found to exert positive effects on plants. A. brasilense, for instance, improved plant nutrition, water and mineral absorption, tolerance to drought and salinity stress, and root growth by increasing the resistance of plants to pathogen attack (Hungary, 2011). According to Gava and Menezes (2012), when T. harzianum is able to colonize the endosperm, it protects the seed and radicle from infection. Interestingly, Trichoderma colonization was found to occur preferentially at specific sites of the rhizoplane, mainly at regions of secondary root emergence and at points of contact between soil and roots, where abrasion occurs. Although a certain degree of root damage by soil is considered normal during development of the root system, it makes plants more susceptible to infection. Trichoderma inoculation may be a solution to this problem.

Inoculation with B. subtilis, P. fluorescens, or T. harzianum was able to control A. flavus in rice seeds (Table 3). The same effect was observed by Reddy, Raghavender, Reddy, and Salleh (2010), who reported growth inhibitions of 72,74 , and $65 \%$ by B. subtilis, P. fluorescens, and T. harzianum, respectively. Yang, Zhang, Chen, Liu, and $\mathrm{Lu}$ (2017) found growth inhibitions above $80 \%$ in the control of A. flavus by P. fluorescens.

Pseudomonas and Bacillus isolates were reported to control the rice blast fungus P. oryzae (Suryadi, Susilowati, Riana, \& Mubarik, 2013). Inoculation with P. fluorescens and Bacillus isolates via seed treatment was effective in controlling the brown spot fungus B. oryzae and the leaf scald fungus G. oryzae in rice (Moura et al., 2014). Another study found that rice seeds inoculated with B. subtilis DFs422 and infected with G. oryzae showed low-severity symptoms of the disease for the first 21 days and became resistant to the fungus after this period (Ludwig, Moura, Santos, \& Ribeiro, 2009).

Biological agents differ in their mechanisms of action. Some exert beneficial effects during seed germination, others during seedling growth, and others may be effective during all stages of the plant life cycle. It is interesting to note that $A$. brasilense has been gaining popularity in recent years as a nitrogen-fixing rhizobacterium (Fibach-Paldi, Burdman, \& Okon, 2012), but its effects are not limited to plant growth promotion. In a pioneering work, Russo et al. (2008) demonstrated that A. brasilense is an excellent biological control agent against Rhizoctonia spp. and, since then, efforts have been made to elucidate its mechanisms of action. The bacterium was shown to produce and secrete phenylacetic acid, which has antimicrobial action against phytopathogenic fungi and bacteria (Somers, Ptacek, Gysegom, Srinivasan, \& Vanderleyden, 2005), and siderophores, which are iron-chelating compounds shown to reduce the incidence of Colletotrichum acutatum in strawberry (Tortora, Díaz-Ricci, \& Pedraza, 2011).

B. subtilis produces a variety of antibiotic substances, including iturine and fengycin, which are inhibitory to Fusarium, Penicillium, Aspergillus, Colletotrichum, and Rhizoctonia solani (Nagórska, Bikowski, \& Obuchowski, 2007); surfactin, which has synergistic effects with fengycin against A. flavus (Farzaneh, Shi, Ahmadzadeh, $\mathrm{Hu}, \&$ Ghassempour, 2016); and bacillomycin, a compound with fungicidal activity (Gong et al., 2014). P. fluorescens produces 2,4-diacetylphloroglucinol, a prominent antimicrobial that inhibits the growth of several phytopathogenic bacteria, oomycetes, and fungi (Couillerot et al., 2011). T. harzianum secrets hydrolytic enzymes, produces fungistatic compounds (Contreras-Cornejo, Macías-Rodriguez, Del-Val, \& Larsen, 2016), and parasitizes other fungi (Silva et al., 2017). All these data support our findings regarding fungi control on rice seeds using biological control (Table 3).

Different pathogens induce different responses in biological control agents. For instance, $R$. solani alters the expression of genes associated with secondary metabolite detoxification and metabolism in P. fluorescens, whereas Pythium aphanidermatum does not (Hennessy, Glaring, Olsson, \& Stougaard, 2017).

Overall, these findings suggest that inoculation of rice seeds with more than one microorganism might be an effective strategy for the control of pathogens (Babalola, 2010). Coinoculation of tomato leaves with 
Trichoderma spp. and B. subtilis, Trichoderma spp. and P. fluorescens, or the three microorganisms combined was more effective against the pathogen Ralstonia spp. than inoculation with a single microorganism or chemical control (Yendyo, Ramesh, \& Pandey, 2018). Similar effects are expected for coinoculation of seeds.

In this study, biological inoculation was found to be more effective in promoting seed vigor and viability and protecting rice seeds from fungi when combined with fungicide treatment (Tables 1 and 3 ). In the absence of fungicide treatment, microbial inoculation was more effective than the control (Table 3). These results indicate that chemical treatment had a much greater effect on seeds than biological treatment, thereby precluding observation of the beneficial effects of biological agents. Fungicide application might have decreased the positive effects of $T$. harzianum inoculation and might even have affected plant responses to $A$. brasilense, $B$. subtilis, and $P$. fluorescens. A previous study showed that fungicides can have deleterious effects not only on fungi but also on bacteria and are not compatible with $A$. brasilense inoculated via seed treatment (Munareto et al., 2018).

Fungicide treatment increased rice seed vigor, viability, and resistance to fungi. Microbial inoculation did not improve the physiological quality of seeds. A. brasilense, $B$. subtilis, $P$. fluorescens, and $T$. harzianum inoculated via seed treatment were effective in controlling $P$. sorghina, $B$. subtilis, $P$. fluorescens, and $T$. harzianum were effective against $A$. flavus, $P$. fluorescens and $T$. harzianum successfully controlled $P$. oryzae and $T$. harzianum was effective against $G$. oryzae.

\section{References}

Abd-Allah, E. E., \& Didamony, G. E. (2007). Effect of seed treatment of Arachis hypogaea with Bacillus subtilis on nodulation in biocontrol of southern blight (Sclerotium rolfsii) disease. Phytoparasitica, 35(1), 8-12. https://doi.org/10.1007/BF02981055

Araujo, F. F. (2008). Inoculação de sementes com Bacillus subtilis, formulado com farinha de ostras e desenvolvimento de milho, soja e algodão. Ciência e Agrotecnologia, 32(2), 456-462. https://doi.org/ $10.1590 / \mathrm{S} 1413-70542008000200017$

Babalola, O. O. (2010). Beneficial bacteria of agricultural importance. Biotechnology Letters, 32(11), 1559-1570. https://doi.org/10.1007/s10529-010-0347-0

Bloemberg, G. V., \& Lugtenberg, B. J. (2001). Molecular basis of plant growth promotion and biocontrol by rhizobacteria. Current Opinion on Plant Biology, 4(4), 343-50. https://doi.org/10.1016/S1369-5266 (00)00183-7

Brasil, Ministério da Agricultura, Pecuária e Abastecimento. (2009a). Manual de análise sanitária de sementes (p. 200). Brasília: MAPA.

Brasil, Ministério da Agricultura, Pecuária e Abastecimento. (2009b). Regras para análise de sementes (p. 395). Brasília: MAPA/ACS.

Brotman, Y., Landau, U., Cuadros-Inostroza, Á., Takayuki, T., Fernie, A. R., Chet, I., ... Willmitzer, L. (2013). Trichoderma-plant root colonization: escaping early plant defense responses and activation of the antioxidant machinery for saline stress tolerance. PLoS Pathogen, 9, e1003221. https://doi.org/ 10.1371/journal.ppat.1003221

Busby, P. E., Ridout, M., \& Newcombe, G. (2016). Fungal endophytes: Modifiers of plant disease. Plant Molecular Biology, 90(6), 645-655. https://doi.org/10.1007/s11103-015-0412-0

Carvalho, N. M., \& Nakagawa, J. (2012). Sementes: Ciência, tecnologia e produção (5th ed.). Jaboticabal: FUNEP. https://doi.org/10.1590/S0101-31222012000200011

Choudhary, D. K., \& Johri, B. N. (2009). Interactions of Bacillus spp. and plants-With special reference to induced systemic resistance (ISR). Microbiological Research, 164(5), 493-513. https://doi.org/10.1016/ j.micres.2008.08.007

CONAB (Companhia Nacional de Abastecimento). (2018). Acompanhamento da safra brasileira de grãos (V.5, Safra 2017/2018-Décimo Levantamento). Retrieved June 20, 2019, from https://www.conab.gov.br/ info-agro/safras/graos

CONAB (Companhia Nacional de Abastecimento). (2019). Boletim Grãos Julho 2019, análise mensal, arroz, fevereiro/março de 2019. Retrieved July 17, 2019, from https://www.conab.gov.br/info-agro/safras

Couillerot, O., Combes-Mevnet, E., Pothier, J. F., Bellvert, F., Challita, E., Poirier, M. A., ... Prigente-Combaret, C. (2011). The role of the antimicrobial compound 2,4-diacetylphloroglucinol in the impact of biocontrol 
Pseudomonas fluorescens F113 on Azospirillum brasilense phytostimulators. Microbiology, 157(6), 1694-1705. https://doi.org/10.1099/mic.0.043943-0

Contreras-Cornejo, H. A., Macías-Rodriguez, L., Del-Val, E., \& Larsen, J. (2016). Ecological functions of Trichoderma spp. and their secondary metabolites in the rhizosphere: Interactions with plants. FEMS Microbiology Ecology, 92(4), 1-17. https://doi.org/10.1093/femsec/fiw036

Corrêa, B. O., Moura, A. B., Denardin, N. D., Soares, V. N., Schafer, J. T., \& Ludwig, J. (2008). Influência da microbiolização de sementes de feijão sobre a transmissão de Colletotrichum lindemuthianum (Saac e Magn.). Revista Brasileira de Sementes, 30(2), 156-163. https://doi.org/10.1590/S0101-312220080002 00019

Corrêa, E. B., Bettiol, W., \& Sutton, J. C. (2010). Controle biológico da podridão radicular (Pythium aphanidermatum) e promoção de crescimento por Pseudomonas chlororaphis 63-28 e Bacillus subtilis BG03 em alface hidropônica. Summa Phytopathologica, 36(4), 275-281. https://doi.org/10.1590/S010054052010000400001

Custódio, C. C., Araújo, F. F., Ribeiro, A. M., Souza Filho, N. V., \& Machado Neto, N. B. (2013). Seed treatment with Bacillus subtilis or indol butyric acid: Germination and early development of bean seedlings. Interciência, 38(4), 273-279.

Farzaneh, M., Shi, Z. Q., Ahmadzadeh, M., Hu, L. B., \& Ghassempour, A. (2016). Inhibition of the Aspergillus flavus growth and aflatoxin B1 contamination on pistachio nut by fengycin and surfactin-producing Bacillus subtilis UTBSP1. Plant Pathology Journal, 32(3), 209-215. https://doi.org/10.5423/PPJ.OA.11.2015.0250

Ferreira, D. F. (2011). SISVAR: A computer statistical analysis system. Ciência e Agrotecnologia, 35(6), 1039-42. https://doi.org/10.1590/S1413-70542011000600001

Fibach-Paldi, S., Burdman, S., \& Okon, Y. (2012). Key physiological properties contributing to rhizosphere adaptation and plant growth promotion abilities of Azospirillum brasilense. FEMS Microbiology Letters, 326(2), 99-108. https://doi.org/10.1111/j.1574-6968.2011.02407.x

Gava, C. A. T., \& Menezes, M. E. L. (2012). Eficiência de isolados de Trichoderma spp no controle de patógenos de solo em meloeiro amarelo. Revista Ciência Agronômica, 43(4), 633-640. https://doi.org/ 10.1590/S1806-66902012000400003

Gong, Q., Zhang, C., Lu, F., Zhao, H., Bie, X., \& Lu, Z. (2014). Identification of bacillomycin D from Bacillus subtilis fmbJ and its inhibition effects against Aspergillus flavus. Food Control, 36(1), 8-14. https://doi.org/ 10.1016/j.foodcont.2013.07.034

Harthmann, O. E. L., Mógor, A. F., Wordell Filho, J. A., Luz, W. C., \& Biasi, L. A. (2009). Tratamento de sementes com rizobactérias na produção de cebola. Ciência Rural, 39(9), 2533-2538. https://doi.org/ 10.1590/S0103-84782009000900023

Hennessy, R. C., Glaring, M. A., Olsson, S., \& Stougaard, P. (2017). Transcriptomic profiling of microbe-microbe interactions reveals the specific response of the biocontrol strain $P$. fluorescens In5 to the phytopathogen Rhizoctonia solani. BMC Research Notes, 10(1), 1-9. https://doi.org/10.1186/s13104-0172704-8

Hossen, D. C., Corrêa Junior, E. S., Guimarães, S., Nunes, U. R., \& Galon, L. (2014). Tratamento químico de sementes de trigo. Pesquisa Agropecuária Tropical, 44(1), 104-109. https://doi.org/10.1590/S1983-40632 014000100014

Hungria, M. (2011). Inoculação com Azospirillum brasilense: Inovação em rendimento a baixo custo (2nd ed., p. 40). Londrina: EMBRAPA.

Lanna Filho, R., Ferro, H. M., \& Pinho, R. S. C. (2010). Controle biológico mediado por Bacillus subtilis. Revista Trópica-Ciências Agrárias e Biológicas, 4(2), 12-20.

Lucca Filho, O. A., \& Farias, C. R. J. (2012). Patologia de sementes. In S. T. Peske, F. A. Villela, \& G. E. Meneghello (Eds.), Sementes: fundamentos cientificos e tecnológicos (3rd ed., pp. 273-370). Pelotas: Ed. Universitária/UFPel.

Ludwig, J., Moura, A. B., Santos, A. S., \& Ribeiro, A. S. (2009). Microbialização de sementes para o controle de mancha-parda e da escaldadura em arroz irrigado. Tropical Plant Pathology, 34(5), 322-328. https://doi.org/ 10.1590/S1982-56762009000500005 
Mastouri, F., Björkman, T., \& Harman, G. E. (2010). Seed treatment with Trichoderma harzianum alleviates biotic, abiotic, and physiological stresses in germinating seeds and seedlings. The American Phytopathological Society, 100(11), 1213-1221. https://doi.org/10.1094/PHYTO-03-10-0091

Mertz, L. M., Henning, F. A., \& Zimmer, P. D. (2009). Bioprotetores e fungicidas químicos no tratamento de sementes de soja. Ciência Rural, 39(1), 13-18. https://doi.org/10.1590/S0103-84782009000100003

Moura, A. B., Ludwig, J., Santos, A. G., Schafer, J. T., Soares, V. N., \& Corrêa, B. O. (2014). Biocontrol and seed trasmission of Bipolaris oryzae e Gerlachia oryzae to rice seedlings. Journal of Seed Science, 36(4), 407-412. https://doi.org/10.1590/2317-1545v36n41009

Munareto, J. D., Martin, T. N., Muller, T. M., Nunes, U. R., Rosa, G. B., \& Grando, L. F. T. (2018). Compatibility of Azospirillum brasilense with fungicide and insecticide and its effects on the physiological quality of wheat seeds. Semina: Ciências Agrárias, 39(2), 855-864. https://doi.org/10.5433/1679-0359.2018v39n2p855

Nagórska, K., Bikowski, M., \& Obuchowski, M. (2007). Multicellular behaviour and production of a wide variety of toxic substances support usage of Bacillus subtilis as a powerful biocontrol agent. Acta Biochimica Polonica, 54(3), 495-508.

Nakagawa, J. (1999). Testes de vigor baseados no desempenho das plântulas. In F. C. Krzyzanowski, R. D. Vieira, \& J. B. França Neto (Eds.), Vigor de sementes: conceitos e testes (pp. 2-24). Londrina: ABRATES.

Pereira, C. E., Oliveira, J. A., Guimarães, R. M., Vieira, A. R., Evangelista, J. R. E., \& Oliveira, G. E. (2011). Tratamento fungicida e peliculização de sementes de soja submetidas ao armazenamento. Ciência e Agrotecnologia, 35(1), 158-164. https://doi.org/10.1590/S1413-70542011000100020

Pereira, C. E., Oliveira, J. A., Rosa, M. C. M., Oliveira, G. E., \& Costa Neto, J. (2009). Tratamento fungicida em sementes de soja inoculadas com Colletotrichum truncatum. Ciência Rural, 39(9), 2390-2395. https://doi.org/10.1590/S0103-84782009005000215

Pomella, A. W. V., \& Ribeiro, R. T. S. (2009). Controle biológico com Trichoderma em grandes culturas-Uma visão Empresarial. In W. Bettiol, \& M. A. B. Morandi (Eds.), Biocontrole de doenças de plantas: Uso e perspectivas (pp. 239-244). Jaguariúna: Embrapa Meio Ambiente.

Ramos, N. P., Marcos Filho, J., \& Galli, J. A. (2008). Tratamento fungicida em semente de milho super-doce. Revista Brasileira de Sementes, 30(1), 24-31. https://doi.org/10.1590/S0101-31222008000100004

Reddy, K. R. N., Raghavender, C. R., Reddy, B. N., \& Salleh, B. (2010). Biological control of Aspergillus flavus growth and subsequent aflatoxin B1 production in sorghum grains. African Journal of Biotechnology, 9(27), 4247-4250.

Reis Junior, F. B., Machado, C. T. T., Machado, A. T., \& Sodek, L. (2008). Inoculação de Azospirillum amazonense em dois genótipos de milho sob diferentes regimes de nitrogênio. Revista Brasileira de Ciência do Solo, 32(3), 1139-1146. https://doi.org/10.1590/S0100-06832008000300022

Russo, A., Vettori, L., Felici, C., Fiaschi, G., Morini, S., \& Toffanin, A. (2008). Enhanced micropropagation response and biocontrol effect of Azospirillum brasilense Sp245 on Prunus cerasifera L. clone Mr.S 2/5 plants. Journal of Biotechnology, 134(3-4), 312-319. https://doi.org/10.1016/j.jbiotec.2008.01.020

Silva, F. F., Castro, E. M., Moreira, S. I., Ferreira, T. C., Lima, A. E., \& Alves, E. (2017). Emergência e análise ultraestrutural de plântulas de soja inoculadas com Sclerotinia sclerotiorum sob efeito da aplicação de Trichoderma harzianum. Summa Phytopathologica, 43(1), 41-45. https://doi.org/10.1590/0100-5405/2212

Silva, C. S., Lucca Filho, O. A., Zimmer, P. D., \& Bonini Filho, R. M. (2011). Efeito do tratamento químico sobre a qualidade fisiológica e sanitária de sementes de arroz com diferentes graus de umidade. Revista Brasileira de Sementes, 33(3), 426-434. https://doi.org/10.1590/S0101-31222011000300005

Simon, H., Smith, K. P., Dodsworth, J. E., Guenthner, B., Handelsman, J., \& Goodman, R. M. (2001). Influence of tomato genotype on growth of inoculated and indigenous bacteria in the spermosphere. Applied Environmental Microbiology, 67(2), 514-520. https://doi.org/10.1128/AEM.67.2.514-520.2001

Smith, L.M., Tola, E., de Boer, P., \& O’Gara, F. (1999). Signalling by the fungus Pythium ultimum represses expression of two ribosomal RNA operons with key roles in the rhizosphere ecology of Pseudomonas fluorescens F113. Environmental Microbiology, 1(6), 495-502. https://doi.org/10.1046/j.1462-2920.1999. 00067.x

Somers, E., Ptacek, D., Gysegom, P., Srinivasan, J., \& Vanderleyden, J. (2005). Azospirillum brasilense produces the auxin-like phenylacetic acid by using the key enzyme for indole-3-acetic acid biosynthesis. 
Applied Environmental Microbiology, 71(4), 1803-1810. https://doi.org/10.1128/AEM.71.4. 1803-1810.2005

Suryadi, Y., Susilowati, D., Riana, E., \& Mubarik, N. (2013). Management of rice blast disease (Pyricularia oryzae) using formulated bacterial consortium. Emirates Journal of Food and Agriculture, 25(5), 349-57. https://doi.org/10.9755/ejfa.v25i5.12564

Tortora, M. L., Díaz-Ricci, R. C., \& Pedraza, R. O. (2011). Azospirillum brasilense siderophores with antifungal activity against Colletotrichum acutatum. Archives of Microbiology, 193(4), 275-286. https://doi.org/ 10.1007/s00203-010-0672-7

Yang, X., Zhang, Q., Chen, Z. Y., Liu, H., \& Lu, P. (2017). Investigation of Pseudomonas fluorescens strain 3JW1 on preventing and reducing aflatoxin contaminations in peanuts. PLoS ONE, 12(6), 1803-1810. https://doi.org/10.1371/journal.pone.0178810

Yendyo, S., Ramesh, G. C., \& Pandey, B. R. (2018). Evaluation of Trichoderma spp., Pseudomonas fluorescens and Bacillus subtilis for biological control of Ralstonia wilt of tomato. F1000 Research, 6(2028), 1-22. https://doi.org/10.12688/f1000research.12448.3

\section{Copyrights}

Copyright for this article is retained by the author(s), with first publication rights granted to the journal.

This is an open-access article distributed under the terms and conditions of the Creative Commons Attribution license (http://creativecommons.org/licenses/by/4.0/). 